\title{
Triplatin Tetranitrate
}

National Cancer Institute

\section{Source}

National Cancer Institute. Triplatin Tetranitrate. NCI Thesaurus. Code C1827.

A cationic tri-nuclear platinum complex related to cisplatin. BBR 3464 binds to and forms

DNA crosslinks and platinum-DNA adducts, preventing DNA replication and tumor cell division. 